\title{
Communication
}

[Comunicação]

\section{Double-staining immunohistochemistry of canine mammary neoplasms}

\author{
[Dupla marcação imunoistoquímica em neoplasias mamárias caninas] \\ F.M. Pereira ${ }^{1}$, E. Ferreira ${ }^{1}$, D.R.A. Leitão ${ }^{2}$, G.D. Cassali ${ }^{1 *}$ \\ ${ }^{1}$ Laboratório de Patologia Comparada - Instituto de Ciências Biológicas - UFMG \\ Caixa Postal 486 \\ 31270-901 - Belo Horizonte, MG \\ ${ }^{2}$ Instituto de Patologia e Imunologia Molecular da Universidade do Porto - Porto, Portugal
}

Studies have proven that immunomicroscopy is a valuable technique in research (Hsu et al., 1981) and diagnostic histopathology and cytology for the identification and classification of tumor cells using of a wide variety of markers (Flens et al., 1990; Taylor and Shi, 1994).

More recently, double immunohistochemical techniques have been developed, allowing two antigens can be simultaneously shown in a single section (Ramsay et al., 1988; Taylor and Shi, 1994; Waiser et al., 2002). Concerning that specifically to the expression of cellular antigens, this method offers a wide range of possible applications (Taylor and Shi, 1994). In human species, the impact of immunohistochemistry has been most effective in surgical pathology in the diagnosis of "undifferentiated malignant neoplasm". In veterinary, immunohistochemical staining can be used to diagnose some kind of tumor lesions, with high sensitivity and specificity, permitting the correct prognostic and treatment of these lesions (Cassali et al., 2001). Furthermore, in mammary neoplasms in canine, tumor type was an important independent factor and a range was observed of increasing malignancy from complex carcinoma (composed of both epithelial and myoepithelial components) to simple carcinoma (composed of one type of cell either epithelial or myoepithelial cells) to sarcoma was observed (Misdorp et al., 1999).

The authors describe their experience concerning standartisation of double-staining immunohistochemistry applied a mammary tumors in veterinary pathology. For this study, four tumors, frequently observed in veterinary medicine, were used ( 2 - benign mixed tumors and 2 carcinosarcomas) (Misdorp et al., 1999). In these tumors, there is a neoplastic involvement of epithelial, myoepithelial and mesenchymal cells, sometimes with cartilage and/or bone neoformation.

Neoplastic mammary tissue was obtained from female dogs following surgical resections and autopsies. Two human cell markers antibodies (Table 1) were used on $4 \mu \mathrm{m}$ sections of formalin fixed and paraffin embedded dog tissues.

Table 1. List of primary antibodies, origin, characteristics and tested dilutions in canine species tissue samples

\begin{tabular}{lcccc}
\hline Primary antibodies & Origin & Antigen Unmasking & Dilution & Main cellular expression \\
\hline Cytokeratin AE1/AE3 & Biogenex, USA & Pepsin & $1: 50$ & $\begin{array}{c}\text { Epithelial cells } \\
\text { S100 }\end{array}$ \\
Dako, Denmark & - & $1: 700$ & $\begin{array}{c}\text { MC, melanocyte, adipocyte, SCM, SC, } \\
\text { chondrocyte, histiocyte and their } \\
\text { correspondent tumors }\end{array}$ \\
\hline MC: myoephitelial cells; SCM: skeletal cardiac muscle; SC: Schwann cells. Cassali et al. (2001).
\end{tabular}

Recebido em 20 de setembro de 2004

Aceito em 23 de fevereiro de 2006

*Autor para correspondência (corresponding author)

E-mail: cassalig@icb.ufmg.br 
The canine tissue sections were deparaffinized in xilol and processed with alcohol, as in routine tissue processing. Enzymatic pre-treatment was performed for cytokeratin AE1/AE3 antibody using $0.4 \%$ pepsin for 30 minutes at $37^{\circ} \mathrm{C}$. Endogenous peroxidase activity was blocked by treating the tissue sections with $10 \%$ hydrogen peroxide in methanol for 15 minutes. The sections were washed twice in phosphate buffered saline (PBS) for 5 minutes each one, after all incubation steps. Human appendix sections were used as positive controls. Negative controls were performed replacing primary antibodies with PBS.

All immunohistochemical steps were performed in a humidity chamber at controlled temperature. A universal staining $\mathrm{kit}^{1}$ (UltraVision Large Volume Detection System Anti-Polyvalent, HRP) was used in the first sequence of the double immunohistochemical technique. For this sequence, sections were incubated with normal serum $^{1}$ (Ultra Vision Block) for $15 \mathrm{~min}$. Then, the sections were incubated with monoclonal primary antibody Cytokeratin AE1/AE3 (mouse $\mathrm{IgG}$ ) for $60 \mathrm{~min}$ and biotinylated secondary antibody (goat anti-polyvalent $\mathrm{IgG}$ ) for $15 \mathrm{~min}$. After incubation with streptavidin peroxidase complex for $15 \mathrm{~min}$, the brown color-developing substrate 3,3'- diaminobenzidine ${ }^{1}$ (DAB) was added for $10 \mathrm{~min}$. For the second sequence, sections were incubated for $15 \mathrm{~min}$ with normal goat serum ${ }^{2}$ (X0907). Subsequently, sections were incubated for $60 \mathrm{~min}$ with polyclonal primary antibody S100 (mouse $\mathrm{IgG}$ ) and goat anti-mouse secondary antibody ${ }^{2}$ (P0447) for 15 min. Following incubation with alkaline phosphatase anti-alkaline phosphatase complex (APAAP Complex) for $15 \mathrm{~min}$, substrate solution consisting of fast red was added. Single cells stained in brown if they are positive for cytokeratin AE1/AE3 and stained in red if they are positive for $\mathrm{S} 100$.
The double-staining immunohistochemical technique, in this case applied to neoplastic dog mammary tissues (benign mixed tumor and carcinosarcoma), showed satisfactory results in the characterization of the cellular types involved with tumor growth and in the classification of these tumors. In the first sequence of double immunohistochemical reaction, the use of diaminobenzidine (DAB) as substrate stained cells in brown. These cells were positive to cytokeratin and identified as ephitelial cells (Fig. 1). In the second sequence of this process, the Fast Red stained in red the mioephitelial cells that were positive to S100 (Fig. 1).

The frequency of benign and malignant mammary tumours in dogs varies considerably due to the existence of different methods of tumor classification and lack of uniform criteria to differentiate these types of tumours. Morphological criteria alone may be insufficient for a proper diagnosis because when only histologically determined, benign tumors may incidentally give rise to metastasis, while canine complex adenomas and mixed tumours often show histomorphological evidence of malignancy (carcinoma or sarcoma in benign tumor) despite benign biological behaviour. Besides, the role of pathologists in the evaluation of tumors is far beyond the exact characterisation of neoplastic histogenesis.

From the results described above, doublestaining immunohistochemistry can be considered a useful technique in research, to diagnose different mammary tumors types and to study of complex clinical cases in which the relation between the tumor type involved in the lesion and its prognostic value needs to be found.

\footnotetext{
${ }^{1}$ Lab Vision, Fremont, CA, USA

${ }^{2}$ Dako, Glostrup, Denmark
} 

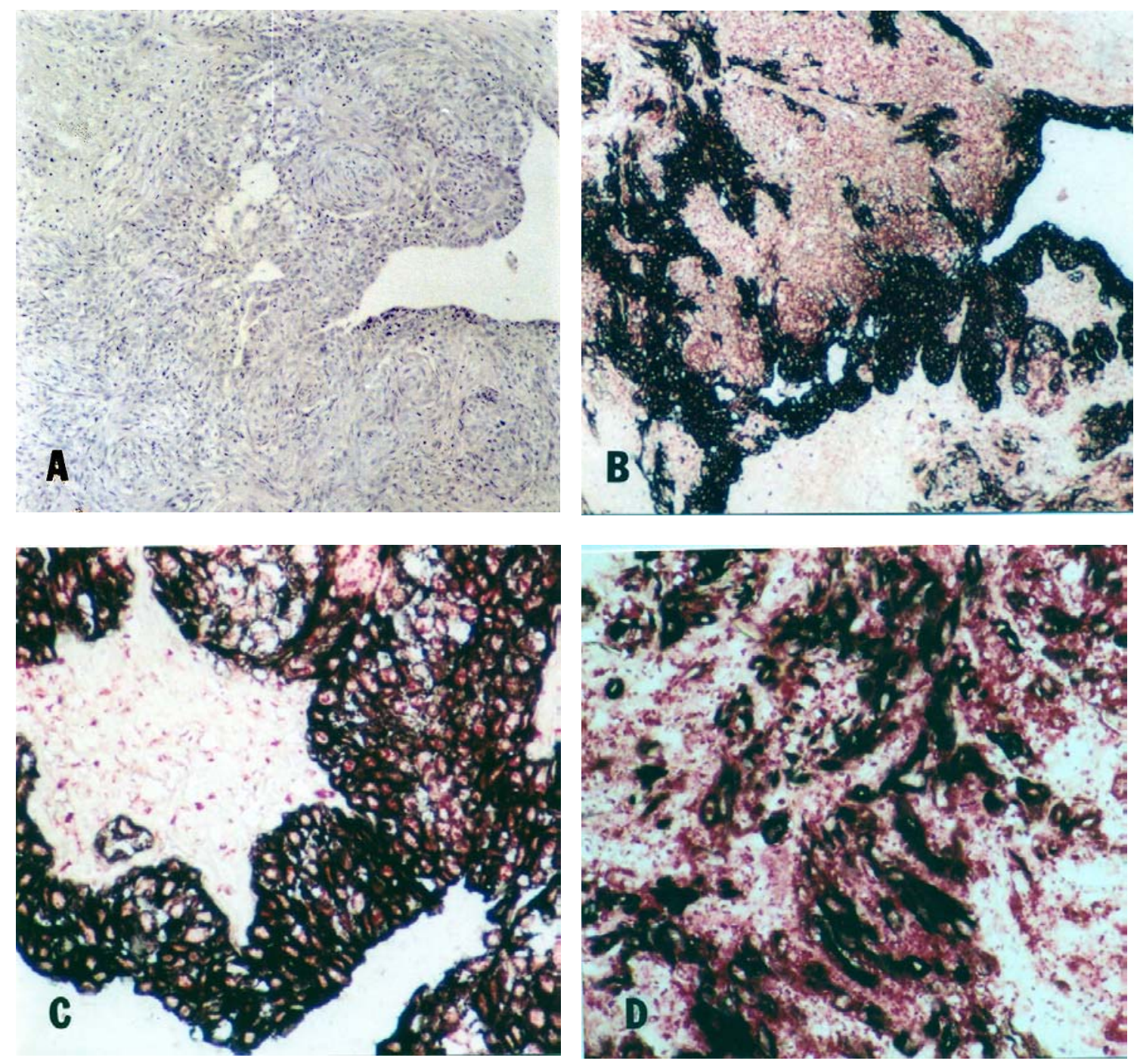

Figure 1. Photomicrographs of canine mammary tumors. A) Benign mixed tumor used as negative control to immunohistochemical staining (Haematoxylin counterstaining). $33 \times$. B) Double immunostaining for cytokeratin AE1/AE3 and S100 in benign mixed tumors. Epithelial cells (brown) are positive for cytokeratin AE1/AE3 and myoepithelial cells (red) are positive for S100. 33×. C) Higher magnification of micrograph B. 132×. D) Double immunostaining for cytokeratin AE1/AE3 (brown) and S100 (red) in carcinosarcoma. $132 \times$.

\section{RESUMO}

Descreve-se a técnica de dupla-marcação em imunoistoquímica aplicada a tumores mamários em cadelas incluídos em parafina. Foram utilizados dois tipos de neoplasia em que ocorre envolvimento de células epiteliais, mioepiteliais e mesenquimais, tumor misto benigno e carcinossarcoma. Foram testados dois anticorpos, AE1/AE3 para identificação de tecido epitelial e S100 como marcador de células mioepiteliais. A dupla marcarcação em imunoistoquímica pode ser utilizada como ferramenta importante na pesquisa e diagnóstico de lesões mamárias complexas.

Palavras-chave: cão, glândula mamária, imunoistoquímica, neoplasia 


\section{REFERENCES}

CASSALI, G.D.; SILVA, P.; RÊMA, A. et al. A new methodology for the improvement of diagnostic immunohistochemistry in canine veterinary pathology: automated system using human monoclonal and polyclonal antibodies. Arq. Bras. Med. Vet. Zootec., v.53, p.326-331, 2001.

FLENS, M.J.; VAN DER VALK, P.; TADEMA, T.M. et al. The contribution of immunocytochemistry in diagnostic cytology. Comparison and evaluation with immunohistology. Cancer, v.65, p.2704-2711, 1990.

HSU, S.M.; RAINE, L.; FANGER, H. Use of avidin-biotin-peroxidase complex $(\mathrm{ABC})$ in immunoperoxidase techniques: a comparison between $\mathrm{ABC}$ and unlabeled antibody (PAP) procedures. J. Histochem. Cytochem., v.29, p.577-580, 1981.

MISDORP, W.; ELSE, R. W.; HELLMÉN, E. et al. Histological classification of mammary tumors of the dog and the cat. Washington, D.C.: World Health Organization, 1999. 59p.

RAMSAY, A.D.; SMITH, W.J.; ISAACSON, P.G. T-cell-rich B-cell lymphoma. Am. J. Surg. Pathol., v.12, p.433-443, 1988.

TAYLOR, C.R.; SHI, S.R. Fixation, processing, special applications. In: TAYLOR, C.R.; COTE, R.J. (Eds.). Immunomicroscopy: a diagnostic tool for the surgical pathologist. 2.ed. Philadelphia, 1994. cap.3, p.42-70.

WAISER, J.; SCHWAAR, S.; BÖHLER, T. et al. Immunohistochemical double-staining of renal allograft tissue: critical assessment of three different protocols. Virchows Arch., v.440, p.648-654, 2002. 